\title{
EXPERIMNTAL STUDIES OF THE EFFECTS OF DIABETES MELLITUS ON MIDDLE EAR INFECTION
}

By

\author{
W. TAKAGAWA
}

\section{From the Department of Oto-Rhino-Laryngology, Faculty of Medicine, Hokkaido University (Director: P.rof. S. Hirano)}

Two groups of rabbits, one with diabetes mellitus deneloped by alloxan injection, and another healthy groups for the contrast were studied. In each group, middle ear infection was developed by staphylococcus aureus injection in tympanic bulla.

The specimens of auditory organs were fixed in Wittmaack's solution, then embedded in celloidin and stained with hematoxylin-eosin.

The results of the examination were as follows:

In diabetes mellitus group; histopathological changes were more remarkable than that in contrast group on following points.

1) External auditory canal: Desquamation of the epithelium, celluler infilltration in subcutaneus tissue.

2) Tympanic cavity: Edema, celluler infiltration and bleeding in mucous membrane.

3) Bone absortion and Multiplication of tympanic cavity and tympanic bulla.

4) Periostal thickening, bone absorption in auditory ossicles.

5) Changes in inner ear were more remarkable and healing of inflammation was slower in diab-

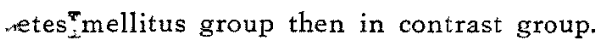

\section{糖尿病の中耳炎に及ぼす影響についての実験的研究}

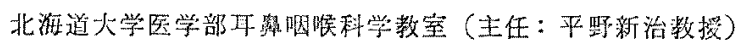

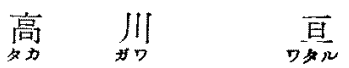

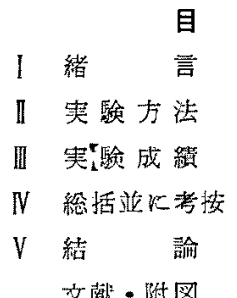

\section{I. 緒}

新陳代謝疾患の一つである糖尿病は身体各部に種々の 障害を起し, 神経炎, 皮澊疾患, 眼疾患, 動脈硬化症,

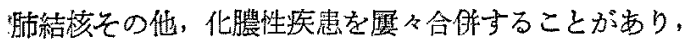
この際生体の抵抗力減弱などのため，臨床上これ等の合 垪症が沿り難いことが従来から数多く報告されている。

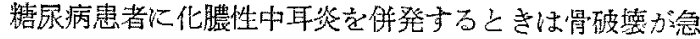

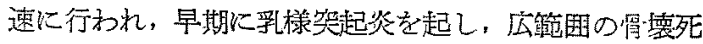
を起し頭蓋内合併症を起与傾向が大であると云われてい る.中耳炎と糖尿病との関係についての文触は Kirchner (1884) 1) 以涹数多く，Rueda (1912) 2) は糖尿病患者

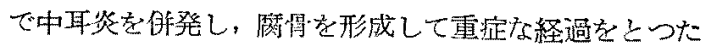
例を報告し，Schlander (1923) 3) は稦症病患者て急性

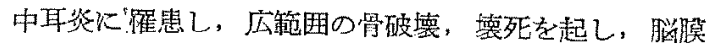
炎，膿血症で死亡した例を報告している，本郝に蛙いて 屯山本 (1931) 15), 犬塚 (1936) 6), 佐藤 (1935) 7), (1938) 8) 等の報告がある．との他糖尿病に中耳炎が合 併した場合の臨床報告例は数多いのであるが，病理組織 学的に記載したものは少く，矢の詳細な所見は未だ明ら 


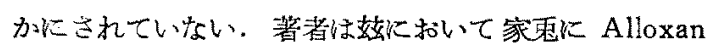

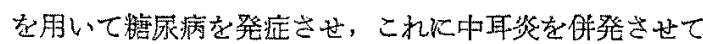
糖尿病の場合に中耳炎がいかなる経過進展を示すがつ

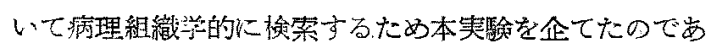
る。

\section{II. 実験方法}

本渠験に使用した動物は体重 $2.5 \mathrm{~kg}$ 前後の成熟家臣 で，外耳道及び䝸朕正常でブライェル上反射正常之認め

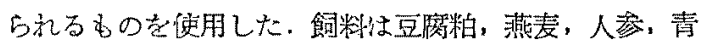

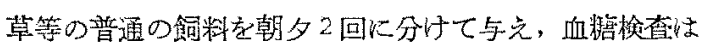
午後了時の定めた時刻に施行した。家雨を Alloxan 注

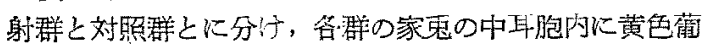
萄状琲菌 (寺島株) を注入して中耳奖を起させ，3乃至 30 日の各時期において断頭又心生体固定を行い, 䏯器 の組織標本を作成して病理組織学的变化を観察した。

1) Alloxan 注射

最初 $5 \%$ Alloxan 水溶液 $200 \mathrm{mg} / \mathrm{kg}$ を家种耳静脈 内に注射したが注射直後乃至数時間後に死亡するすのが 多からたので，以後仕 $130 \mathrm{mg} / \mathrm{kg}$ を注射して艙尿病を 発症させた. Alloxan 注躬によりて注射後 2〜3 時間以 内に一過性の高血糖が起り，次いで 5 12 時間に強い但 血核の時期が䋨くが，この時期に糖液の補粭を行わない

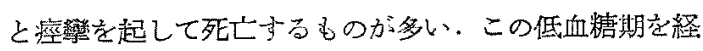

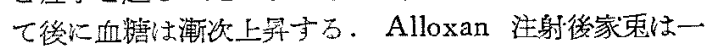
時與䍜状態となるが次第に運動不活発となり食欲る幾ら か低下した。

2)血糖剆定

採血は耳髅脈上り行い，Crecelius-Seifert 氏法によ つた．Alloxan 注射前及び注射後3日目毎に血榶を溉 定し去。

c) 尿糖测定

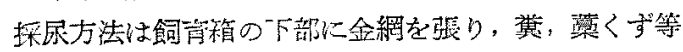
が混じないよらにして下部に大きな源斗を置いて尿を採 取した。原糋の测定は Benedict 氏法により試䕀 $3 \mathrm{cc}$

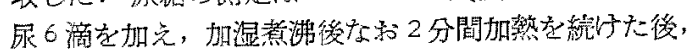
放置领却して下記の表に征つて判定した。

\begin{tabular}{|c|c|c|c|}
\hline 記号 & 液 & 沈 源 & 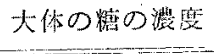 \\
\hline- & 㛭 热 & 数 & \\
\hline \pm & 青禄色 & is L & $0.02 \%$ 以下 \\
\hline+ & 青緑蜰 & 薮緑色 & $0.02 \sim 0.2 \%$ \\
\hline$H$ & 青緑色 & 赤褐色 & $0.2 \sim 0.5 \%$ \\
\hline $\mathrm{HH}$ & 緑 色 & 赤褐色 & $0.5 \sim 1.5 \%$ \\
\hline HII & 無色透明 & 赤色 & $1.5 \sim 2 \%$ 以上 \\
\hline
\end{tabular}

4) 菌注 入

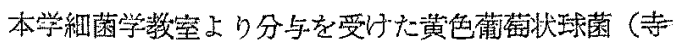
島株）の 1 白金耳（約 $2 \mathrm{mg}$ )を $1 \mathrm{cc}$ の生理的食塩水以 浮游させ、ッベルタリン注射器を用いて敖臊穿刺して中 耳胞内に $0.2 \mathrm{cc}$ 宛 1 回注入を行つた。Alloxan 注射群 に対して心 Alloxan 注射て栯辰病発症1力月後に菌注 入妾行つた.

5)体重湘定

Alloxan 注射前及び断頭又は生体固定時に测定した。

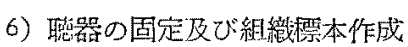

大多数は断頭固定を施したが生体固定によつたものも。 ある. 固定液は Wittmaack 氏固定液を使用し，脱灰 液は $10 \%$ フオルマリン液に5\%の割合に局方硝酸を加 えたるのを使用した、脱灰後 $5 \%$ 硫酸曹達夜で中知し， 水洗, 娜础アルニールて脱止, ッニロイジン包䀘を行い

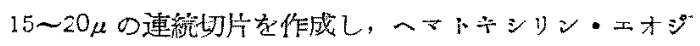
ン雷染色を行つた。

\section{III. 実験成綪}

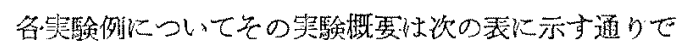
ある。

\begin{tabular}{|c|c|c|c|c|c|c|c|c|}
\hline & \multirow{2}{*}{$\begin{array}{l}\text { 家 } \\
\text { 震 } \\
\text { 番 } \\
\text { 号 }\end{array}$} & \multicolumn{2}{|l|}{ 体 } & \multirow{2}{*}{ 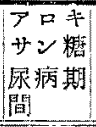 } & \multirow{2}{*}{ 血糖 } & \multirow{2}{*}{$\begin{array}{l}\text { 展 } \\
\text { 粕 }\end{array}$} & \multirow{2}{*}{ 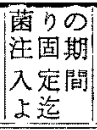 } & \multirow{2}{*}{ 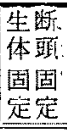 } \\
\hline & & 前 & 後 & & & & & \\
\hline \multirow{7}{*}{ 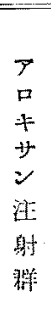 } & 6 & $\begin{array}{r}\mathrm{gr} \\
2550\end{array}$ & $\begin{array}{r}\mathbf{g r} \\
2700\end{array}$ & $\begin{array}{c}\text { 日 } \\
30\end{array}$ & $\mathrm{mg} / \mathrm{dl}$ & + & $\begin{array}{l}\text { 日 } \\
3\end{array}$ & 4 \\
\hline & 7 & 2800 & 2900 & 30 & 180 & $H$ & 5 & 4 \\
\hline & 4 & 3700 & 3500 & 30 & 260 & + & 7 & 4 \\
\hline & 3 & $\approx 800$ & 3750 & 30 & 375 & HA & 14 & 断 \\
\hline & 34 & 2700 & 2600 & 30 & 220 & HH & 14 & 生 \\
\hline & 58 & 2400 & 2500 & 30 & 170 & $H$ & 21 & 生 \\
\hline & 1 & 2600 & 2900 & 80 & 200 & + & 30 & 䉼 \\
\hline \multirow{3}{*}{ 㞶 } & 21 & \multicolumn{2}{|c|}{2600} & & 90 & - & 3 & 4 \\
\hline & 24 & \multicolumn{2}{|c|}{3500} & & 95 & - & 5 & 断 \\
\hline & 18 & \multicolumn{2}{|c|}{2700} & & 85 & - & 7 & 断 \\
\hline \multirow[t]{2}{*}{ 照 } & 32 & \multicolumn{2}{|c|}{2600} & & 90 & - & 7 & 生 \\
\hline & 15 & \multicolumn{2}{|c|}{2500} & & $100^{\circ}$ & - & 14 & 断 \\
\hline \multirow[t]{2}{*}{ 䖽 } & 19 & \multicolumn{2}{|c|}{2800} & & 90 & - & 21 & 断 \\
\hline & 38 & \multicolumn{2}{|c|}{1900} & 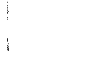 & 80 & - & 30 & 生 \\
\hline
\end{tabular}

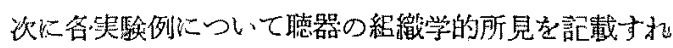
ば次の通りである。

No. 21 刘照例, 菌注入後 3 日目

外耳道：多量の好中球，单球，好酸球並びに一部出

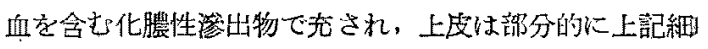


胞浸潤のため，侵触性の脱落去示している所がある・皮 下組繶计中等度若しくはそれ以上の単球及び好中球を主 体とした細胞浸潤があり，該部に和ける血管はいずれも 搪張，充盈を示し，血管内皮細胞の增生並びに円形細胞

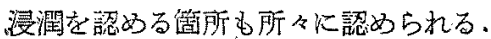

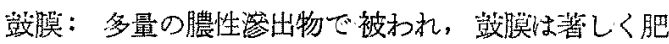

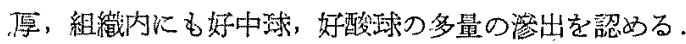
上皮細胞の增生も目立つ。

中耳胞：粘膜上皮圈には部分的ではあるが中等度若 乙くはそれ以上飞笚球，好中球等の浸潤方認められ，該 部は好中球を主体とした膿性渗出物で被われている。粘

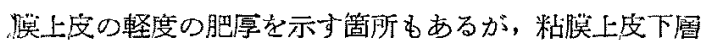
は浮腫を示し中等度の充血及び軽度若しくけ部分的に中 等度の円形細胞浸㵎をみ、る他藷变はない。

話室：好中球及び単球を主体とした膿性渗出物が出

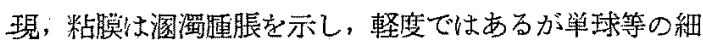
胞浸潤が留められる。

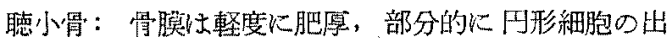

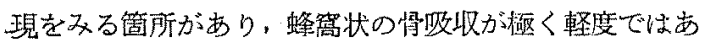
るが認められる。

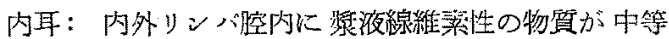
度に認められ允血が周立つ、膜迷路壁には溷濁腫脹, 軽 度の単球等を主体とする円形細胞漫㴸がみられる。

No. 6 糖尿病例, 菌注入後 3 日目

外耳道：多量の好中球，赤血球，好酸球等上りなる 膿性渗出物で充されその一趴恃上段内に侵入，上皮の破 壊消失が強く認められる所がある。度下組織化も高度の

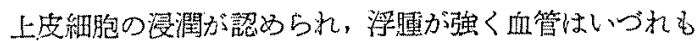
高度の充盈を示し，炎性細胞の漫潤が著しい，上皮の離 䑫の著しい所もある。

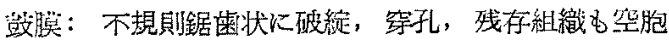

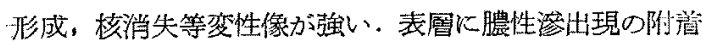
分認められる。

中耳胞：多量の出血性膿性滲出物で充され粘膜上皮

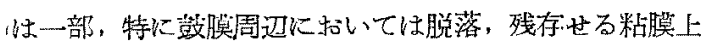
这も膨化变性像が著しい，粘膜上皮下圆は浮喠状でかな り広筈国に旦万出血在認め好中球, 好酸球, 単球, リン 、球等の中等度の細胞浸潤が認められる。悄壁は部分的

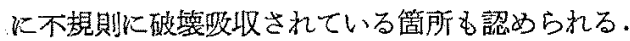

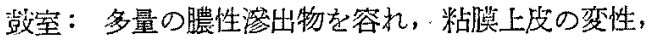

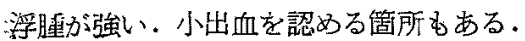

聴小骨：骨膜の肥厚は部分的にかなり強々，中等度 の円形細胞の浸潤があり, Havers 氏腔梳㹡大, 血管周
囲儿性軽度ではあすが細胞浸潤を認め充血が渚しい。な

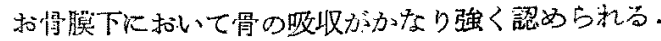

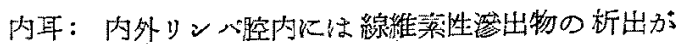
西り，膜迷路壁は浮腫が強く，リン八球，好中球之の他 円形細胞浸潤が中等度に認められ充血子高度で市る..

No. 24 対绍例，菌注入後5日月

外耳道：多量の膿性亚びに出血性法出物の出現があ

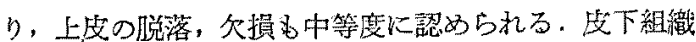
は浮腫性变化が強く，好中球，リン八球等を主体とした 中等度の細胞浸㵎があり，表皮内にも多数の円形細胞浸 潤が認められる。

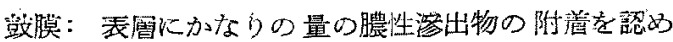
ると共に，組緆内にも好中球，単球等の中等度の細胞浸 潤があり出血を認める筐所も存在している。

中等胞：胞内に蹬粒球，単球を含む線維菜性出物

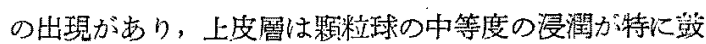

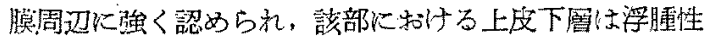
で充血が柾めて强いが 付形細胞浸潤心比較的軽度であ る・骨壁の变化は殆んと認められない。

没室：粘膜内に小出血巣すり，腔内にはか应り多量 の線䊒梨性渗出液を認める。絬膜上皮の膨化胴大が目立 ว.

聴小骨：骬朕は肥厚血管は充盈を示すが特記すべき 変化汱ない。

内耳：内外りン八舼化少显の線維索性滲出物の出現

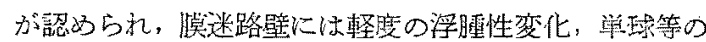
少量の細狍浸㵎が楒められる。

No. 7 糖厐病例, 菌注入後 5 日日

外耳道：極めて多量の膘性滲出物て被加儿，一部赤 血球の出現をみる筒所もある。上货の変性も著しく，円 形細胞の高度の漫潤が認められる。な招かなり強い上皮 の增生, 舥大の認められるる所もある。

毁膜：赤血球在含む膿栏物質で被われ 学球等の中等 度の細胞浸潤が存在する。

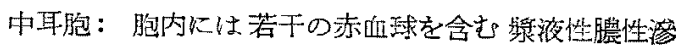

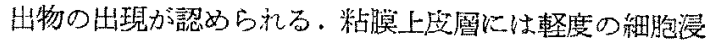
潤があり上㳊下兽は一部膨化，軽度の細胞浸潤が認めら れる。な特特に外耳道に近い骨壁性類骨組織の新生が出 现し始めるが一部骨質の吸收を及る箇所もあり，两诸は 不規則な形に混在している。

鼓室：大体中耳胞の所見に類似するが特に 溶出液の 滶溜が目立つ。

聴小骨：情朕は概して肥厚，骨質の蜂窝状吸収が目 
立o.

内耳：内りン八腔内にリン八球, 単跳, 線維䒺より

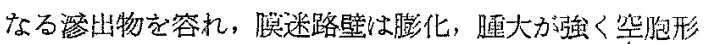
成，核消尖等䏅死々楩つている所むあり充近が著しい 強い颗粒球の細胞浸潤が認められる。

No. 18 対照例, 菌注入後7日目

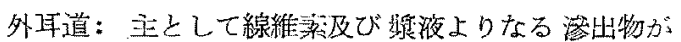

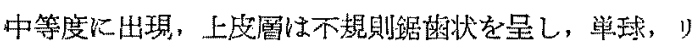
ンハ球等の中等度の浸潤が認奶らる。皮下組繳は肥 厚,リン八球、線䊒芽細胞等の出現が目立ら充血も瑟し い、な拈上皮の变性欠損を示方所もある。

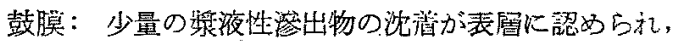
部分的に単球等の軽度の浸潤ぶ認められるのみである。

中耳胞：少量の漿液性渗出物が存し，小部分的では あるが俥度若しくは中等度の単球,あるいはりンく球等 の浸潤が粘臊内記認好られ，粘膜は概して肥厚浮腫状を

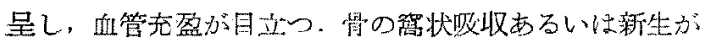
軽度に認められる。

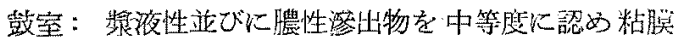

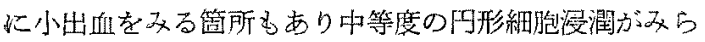
机る。

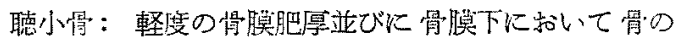
签状吸收が慇められるが特記すべき程の所見はない，

内耳：内外リンパ空内に 軽度の綄維揱性棇出物の出

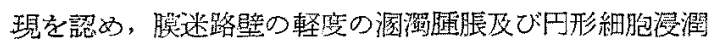
が認められる。

No. 32 対照例, 菌注入後7日目

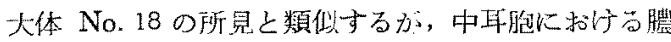

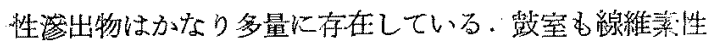

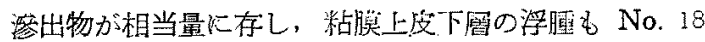
に比べて強い上うに思和る。

No. 4 精尿病例, 菌注入後7日目

外耳道：血性膿性滲出物を多量に含み上枝は变性脱 落等のため不規則鋸料状山凸を示し，好中球，リン八球 等多数の細胞浸潤が認めら机る。店下組織认強い, 円形細

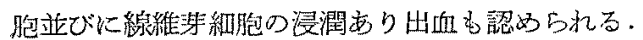

敋膜：単球，リン八球等の細胞浸㵎が中等度，值性

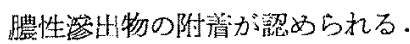

中耳胞：多量の赤血球を含む膿性出出物を容机粘膜

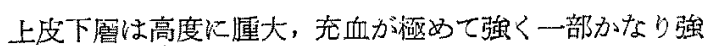
い出血をみる所るある。な招軽度若しくはそれ以上の円 形細胞浸潤が該部に認められる。

鼓室及び聴小骨における変化も対照例に比べて著し

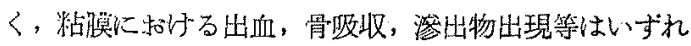
あ高度である。

内耳：变化か漒く，膜迷路壁の細胞浸渥主びに出血 が目立つ。

No. 15 対照例，菌注入後14日目

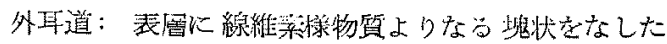

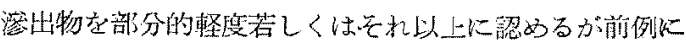

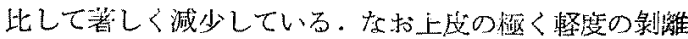
が認められ名が潰揚形成はない，鼓膜の附近では上皮乳

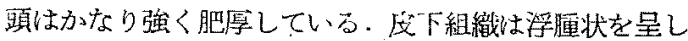

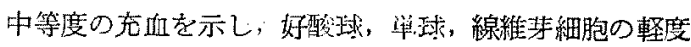
の出王を衿める。

鼓膜：一部軽度の 単球様細胞の漫潤を認めるが特記 すべき所見はない，

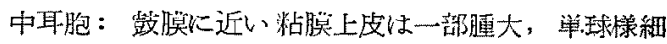
胞の整度の出現を認めるが，一般に著变はない，線維非 栐物貿を主体とした軽度の渗出物の出現が認められる。 粘膜上皮下層にはりッ八球，单球等の軽度の出現が認め られる。類骨組織の整度の出現がある。

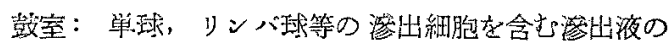
中等度の渚溜が認められ，粘脱上皮下層は浮重充血を欢 るが游走細胞の出現はかなり軖度となつている。

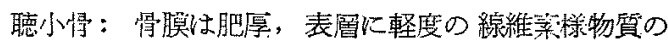
沈㦈を認めるが変化は軽い、

内耳：内リン八腔内に柽度の 線維菜様物質の出現が あるが嚍迷路壁には異常細胞等の出現はなく充血る軽 い.

No. 3 糖䲩病例, 菌注入後 14 日目

外耳道：単球，リンバ球等を含む淩出物がかなり强 く存し，上皮酒には軽度ではあるが細胞浸溉が認めら

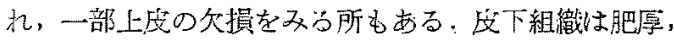

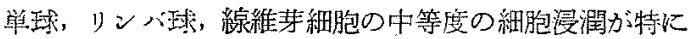

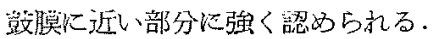

鼓膜：肥㕍を示し，山等度の単球，リン八球，姆酸

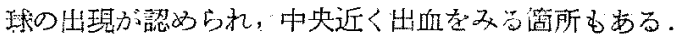
涳出物の附着承強い。

中耳胞：糊璄上皮下湿は特に肥愿と充血が著明で外 耳に近い部分では特に好中球，単球，リン八球等の出現

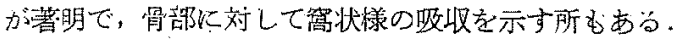

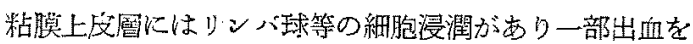

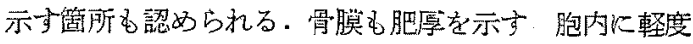
の沴出物の出現をみる。

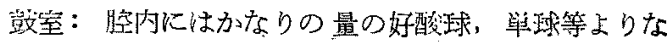


る荟出物を容れ特に鼓膜に近い、部分の粘朕に新しい肉菭

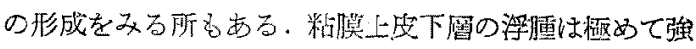
い.

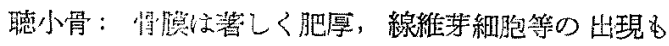

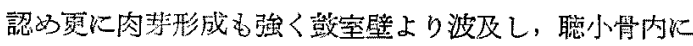
突入し，部分的には聴小愲の大半を充している所もあ る.

内耳：内リシバ腔内に線維菜证びに少量の棇出細胞 を含む泫出液がみられ，腹迷路壁には学球細胞の軽度の 出現をみる・充血がかなり強い。

No. 34 輤尿病例, 菌注入後 14 日目

外耳道：上皮の脱落が 所々ににみられ，上皮層には

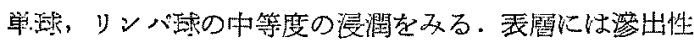

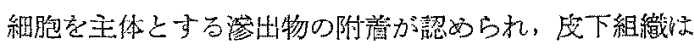
肥厚, 細胞浸濯毛目立つ.

鼓膜：穿孔が大きく，中等度の単球，リン八゙球，好 酸球の出現が認められる。

中耳胞：粘臆上皮佂著しく肥學し不規則な山匹を示 し, 多数の好中球，单球等の細胞漫潤が認められ且つ胞

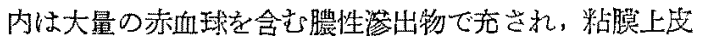
下層では細胞浸潤が椣めて強く充血が高度，小出血をみ

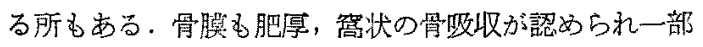
類骨組織の出現をみる所るある。

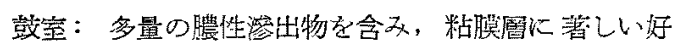
中球等の細胞浸潤が認められる。

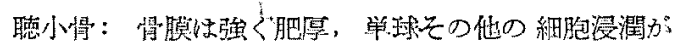

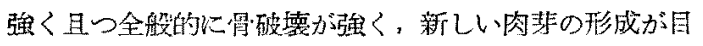
立ち㯖小瑁内に波及，骨内を䇴している所もある。対照 例に比べて病変注極めて高度である。

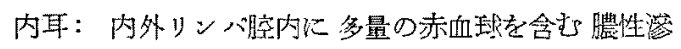
出物の出現があり, 成迷路壁の变化子高度で焱性細胞浸 潤も極めて高度である。

No. 19 対照例, 菌注入後2 1日目

外耳道：外側に近い所では上皮の菱縮はかなり強い

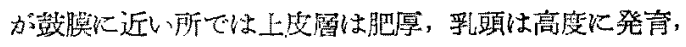
皮下組織名肥厚, 線維身細胞, 単球等の細胞浸潤が軽度

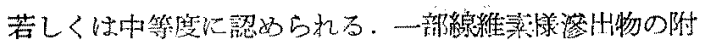
首をみる。

鼓膜：一部かなり強い肥厚を示し，中等度の新しい

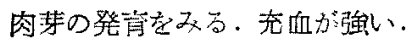

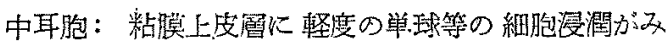
られ一部膨化，粘膜上皮下䤊の肥厚をみる所すある。骨 組織怯軽度の新生を示している。

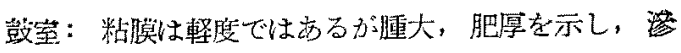

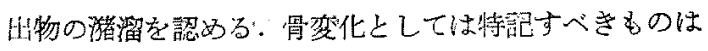
ない.

聴小滑：骨償は軽度に肥厚，胃変化として骨新生る 偠かながら認るら礼る。

内耳：内りンハ腔付に網状線維独様渗出物を容れ，

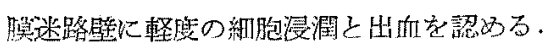

No. 58 糖尿病例, 菌注入後 21 日目

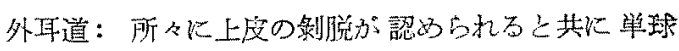

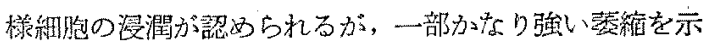

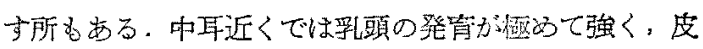
下組䌬も浮腫性で単球，組織球，線雏茅細胞の出現が認 められる。

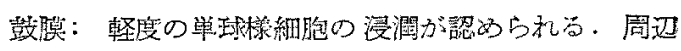

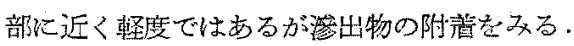

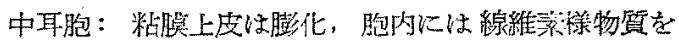

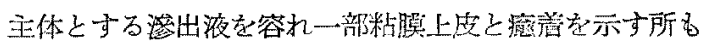

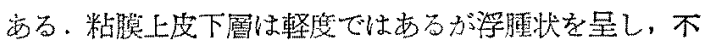
規則な骨吸収が軽度ではあるが認められ，更に新に類骨 新生をみる䇫所古ある。

陪室：かなり多量の滲出液を充し，粘膜上皮は膨化， 一部脱落を示している所もある.粘朕上皮下图は浮腫， 軽度の単球様細胞の出現をみる。

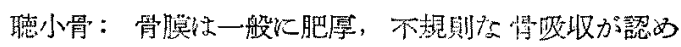
られる。

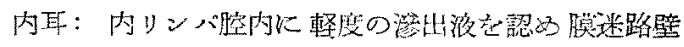
は膨化を示すが樶して者变はない

No. 38 刘照例, 菌注入後 30 日目

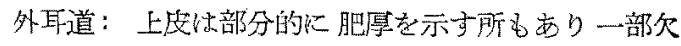

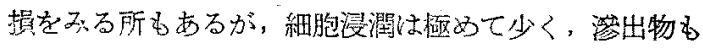
認められない，上皮上屡恰有化を示している，皮下組織 は一般に浮腫性であるが，乵常細胞出晲は認められな い.

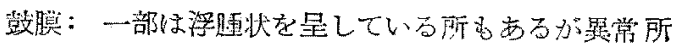
見は殆儿どない，

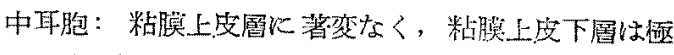
わて軽度の浮腫を示す他，こ〉にも特詰すずき变化は諗

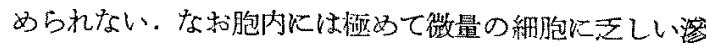
出液を容れている。骨部に異常は認めらない。

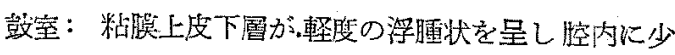
量の線維素样物質を容れているが一般に畒变は認められ ない.

聴小骨：Havers 氏腔の 軽度の掂張をみる他著变は 
認められない。

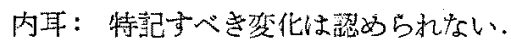

No. 1 精尿病侧, 菌注入後 30 日目

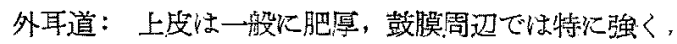

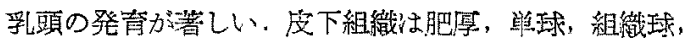

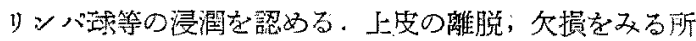
るある。

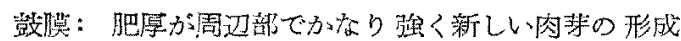
も諗められ，特に周辺では線維莱細胞の出現に混じて等

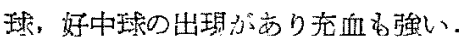

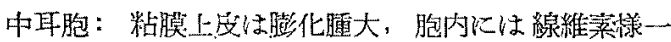

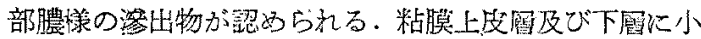

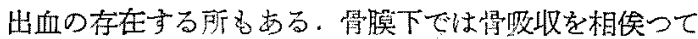
類骨新生も認如的る。

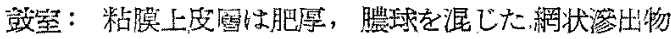

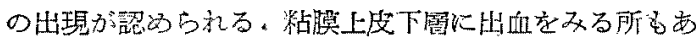
万.

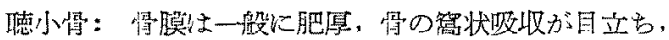
Havers 氏轻はむしろ搪大を示す。

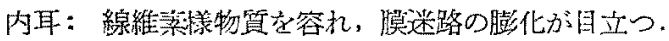
組織所見小括

3日目：対照例 (No. 21) に比べて榶尿病例 (No.6) では外耳道上皮の破壊消失，皮下組職の炎性細胞の浸

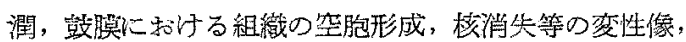
中耳胞粘脵上皮の変性, 上皮下屬の浮腫, 細胞浸潤, 出 血，骨部の吸収方強い,内耳に福ける変化も強い。

5 日目：対照例（No. 24）に比へてて, 糖尿病例 (No. 7)では外耳道上皮の变性，肥大，增生，皮下組織の細 胞浸潤, 中耳胞における粘㬴の細胞浸潤, 頑骨組織の新

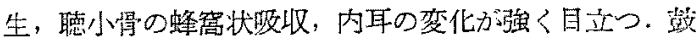
償の変化は両者に大差は認ぬられない。

7 日目：附照例 (No. 18, No. 32)) K比心七㻈尿病

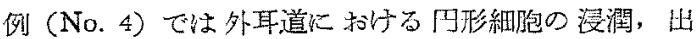
血, 盢膜の紐胞漫潤，中耳胞の粘膜の腫大，充血，出

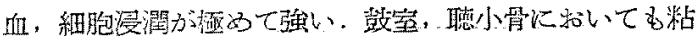
腰骨膜における出血，骨吸收，出物出現が高度であ

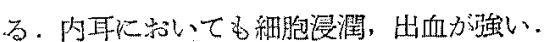

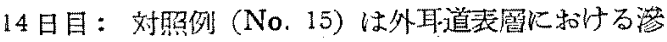
出物は7日目例より箸しく減じているが糖尿症例では澺

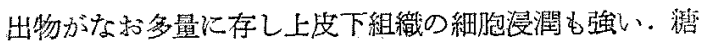

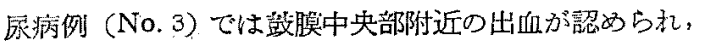

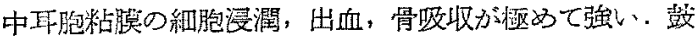
室及び德小骨に肉絜が認められ内耳の充血が強い。
21 日目：対照例（No. 19）に比べて榶尿病例（No.

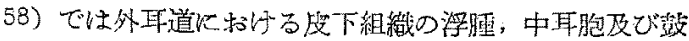
室粘朕の浮雷, 骨壁の吸收、新生が強い，聴小骨の变化 も強い，㖕膜では大差が認められない。

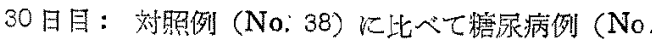
1)で外外耳道上皮の離脱，乳頭の発瓷，峃球，組織球，

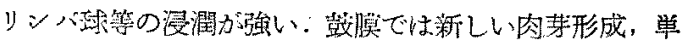
球，好中球の出現が強い，中耳胞では No. 38 《粘欩の

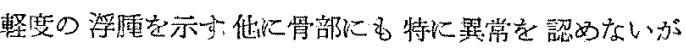
No. 1 ではな和胞内に澧搛澄出物を認め粘膜に出血, 骨膘下では骨吸彼及で新生が認められる。登室，㯖小骨 では刘照例では殆んど变化が認められないが No.1で

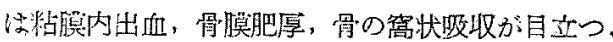

\section{IV 䌊括並に考按}

以上の成㺓を総括すると糖尿病群では刘照涪に比べて

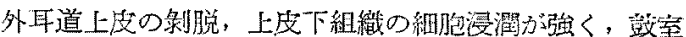

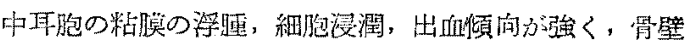

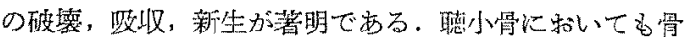

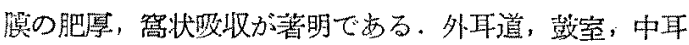

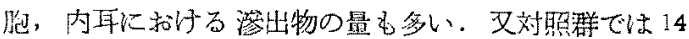
日目から絬膜の浮腫が少くなり炎症像が少くなつてきて

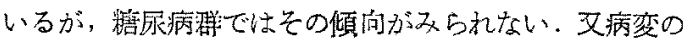

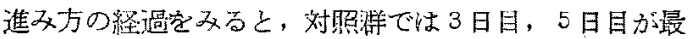

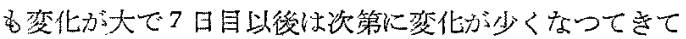
いる.一方糟尿病群では3日目，5日目，7日目上りる 14 日目の方がより変化が強くなつている。これは No. 3, No. 4 が血糖值が他に比べて高かつたことも原因の

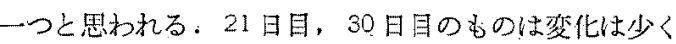

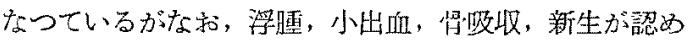
られる。3日，5日，7日，14日，21日，30日の各時期 の病变の状態を比較してみるといずれの場合も糖尿病群 の病変が高度である。

获において再び中耳焱と糖尿病の合倠せる場合につい ての文献をみると Kirchner (1884) 11), Rueda (1912) 12), Edgar (1915) 4) を站的として数多々 Schlander

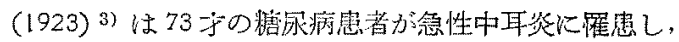

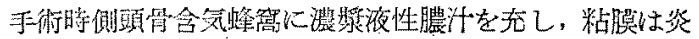

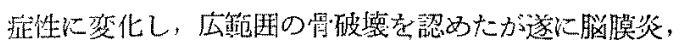
勝血症で死亡した例を報告し，その中で糖尿病患者の急

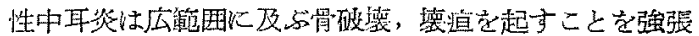
している. Bernfeld, K. (1926)92は6例の慢性中耳桨

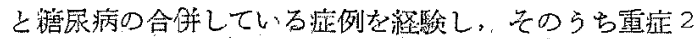

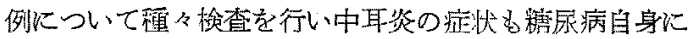


関媇があると述へてている、統計的には Olrik. B. 10)に 上れば 2866 例の化膿性中耳炎中 11 例が糖尿病を合併 し、そのらちつ例が手術を触行されたが約 $50 \%$ の死亡 率であつた. 又 Mygind，H. 11) は約 1500 例の中耳炎 を沿潦してその中に 6 例の糖尿病を認めたが 6 例中 5 例

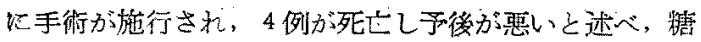
尿病の場合，中耳炎は一般化慢性の経過索之るか，しば しば合併症を起すことが多いと述べている、Grossmann 19にによれば中耳炎で入院した患者中，糖㽷病患都はて の72.7\%，非糖尿病患者は $56.3 \%$ が手術学余義なくされ たように糖尿病患者では合併症の発生が高率である。そ の他，現在迄多数の症例が報告されているが糖尿病の場 合, 中耳资の経過が重篤であることには一致している。 著者の実験成績も糖㡾病の場合, 中耳焱の病変が高度で あり，諸家の絽床報告例と一致していることを示してい る.

次に著者の漹駼をふり返つてみると，著者は Alloxan に上つて家雭に糖展病を発症させたのであるが，糖尿病

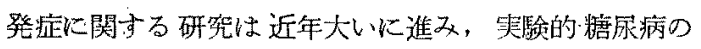
発症方法としては愺摘による方法 (Mering \& Minkowski) 13), 脳下垂体前䔞卫门穴投与飞上る方法 (Haus-

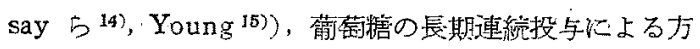
法 (Dohan \& Bailey) ${ }^{16)}$, Alloxon 注射による方法 (Bailey \& Bailey) I') 等数多〈報告されている.Allxan 注射火よつて糖尿病が発症するのは Alloxan が㵏臓の $\beta$ 細胞に選択的に作用して買死を起すためであることが

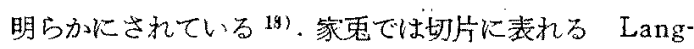
erhans 旦島1個内に快均 $\boldsymbol{\alpha}$ 細胞 13個, $\beta$ 細胞 38個 であるが Alloxan 等の投与で $\boldsymbol{\alpha}$ 細胞は2 2 5 日後に

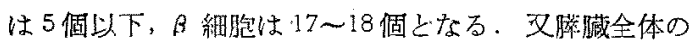
Insulin 含有量は1/8〜1/36亿激减することも認るられ ている.Alloxan 等の化学試蔝によつて発症した䊀展 病は人体の糖尿病と類似の点が多い。

喾尿病の場合; 中耳炎の病変が高度であるのは低抗性 が減弱するためと考光られるが，搳尿病の場合何故忽感 染性であり，低抗力が減弱するかについての研究は各 万面から進められている。内分泌関傒では Insulinの 不足があり，脳下垂体，副霄系については Alloxan 籍

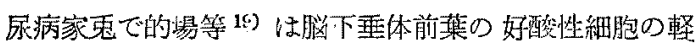
度增加之好塩基性細胞の軽度減少を認邓，池本20) は脳 下垂体前葉細胞の退行性变性を認めている。近藤等 21 は脳下垂体後葉，間䏶視索上核，脳空寄核に扣ける Gomori 陽珄顆粒隇少の傾向を認め，副腎皮質では
Cortical hypertrophy の像で細胞の肥大，增殖を認め ていら. 平田22) は剔腎剔出後，低血糖をきたした場 合, Cortison 投与に上つて速加に糖尿病状態に移行す ると云つている、衛藤等 28) は Chlorpromazin が Alloxan 糖尿病発症抑制するのは植物神経熙断火よ る脳下垂体副琴系関与の抑制之考光度いと云つている。 これ等のことから考兄て桾尿病の場合，脳下垂体副䇰采

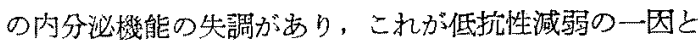
なると思われる。

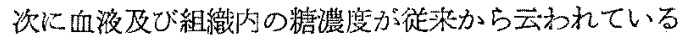
が，美験的には煡康な組織では 0.2 0.3\%位迄の䌅濃度 では障害はないが，ある檑障害組織に対しては低漲度の 糖でも有害性に動くことが認められている24).

又 Alloxan 糖尿家東で抗体産生能の低下，Opsonin 指数の低下，皮下組被の 墨汁資哙能低下，血清の踝菌

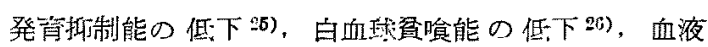
Catalase の減少, 血獎 Catalase の增加 ミが認められ

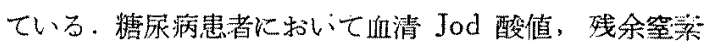

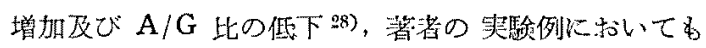
粘膜内出血を多く認めたが，毛細血管抵抗性の減弱 29)，

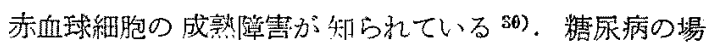
合，動脈硬化症を合併することが多いが，踺の処理能力 の低下のみならず，蛋白，脂質代謝も陴害され，脂肪代 謝の異常から血中にヒ・ヨレステリシ等が堌加して動脈硬 化症が丟机，こ机む抵抗性減弱の一正上なり得ると考克

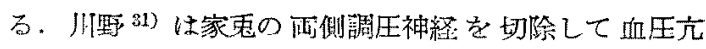

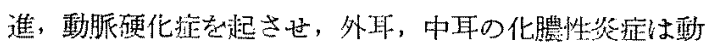

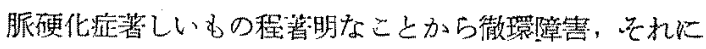
よる栄善障害から生体の抵抗力減退をきたすためである

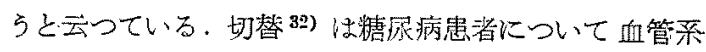
之関保市る諸疾蚛（高血压症, 動脈硬化症等) を合併す

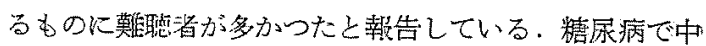
耳资を起した埸合, 旦期に骨に著明な变化をきたすこと

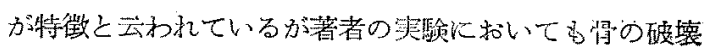
吸収等の变化が著明であることを認めている。骨柔統の

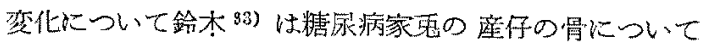

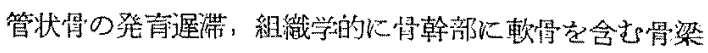

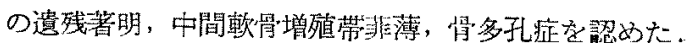
加藤 ${ }^{34)}$ は耳下腺の退行性変化, 㖒骨細胞の変性菱縮, 骨では吸收元進，添加骨皿減少に上る骨多孔淀像を認

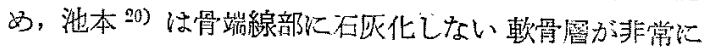
幅広く存在しているのを認めている。阿部 35)は Alloxan 糖尿病家象で骨折時血清 $\mathrm{Ca}$, 無機 $\mathrm{P}$ 量は最高値 
に達する時期が正常のむのより䄪7日好くれ，骨折治瘾

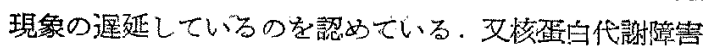
の結果. Allaxon が，又トリプロフアン代謝過程でキサ ンッレン酸生成の可能性が明らかにざれ，これ等による

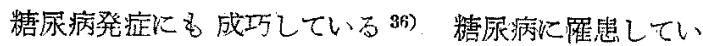
る生体内に有紫物貎の存在が考克られ，このため啸の及 ならず蛋白脂肪代謝にも障害を起し生体に不利な影響を 及社すと考古尚。

糖尿病の第合は以上記した種々の昰い案件が重つて抵 抗力が減弱するため，中耳焱泥患した場合も病変が高 度で経過る長くなるものと考える。

\section{V, 結 論}

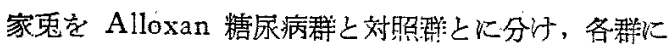
黄色葡萄状球菌で中耳炎を起させ，特に病理組織学的立 場から次の結論を得た。䌅尿病群で棜照群に比べて

1) 外耳道上皮の剥脱，皮下組織の細胞浸潤力強い。

2）鼓室，中耳胞において粘償の浮腫，紬胞浸潤，出 血傾向が強い。

3）政室，中耳胞の骨壁の骨吸収，新生が強い。

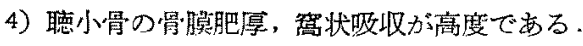

5)内耳の病変が強い。

6）治㴔傾向がおそい

\section{文 献}

1) Kirchiner: Arch. f. O.H. $22: 16,1884.4)$ 上り 引用. 2) Rueda: Mastoiditis, bei einem Diabetiker. Monatscer. f. O.H. 66 J. 1349, 1912 . 3) Schtander: Otitis media acuta, Diabetes mellitus, $\mathrm{Me}$ ningițis purulenta, unter dem Bilde einer Pyämie verlaufend. Monatschr. f.O.H. 57J. 513, 1923.

Edgar,Th. O.: Klinische Untersuchungen über die Erkrankungen des Gehörgangs bei Diasbetes mit besounderer Berücksichtigung der Erkranung des inneren Ohres. Monatschr. f.O.H. 69J. 225, 1915.

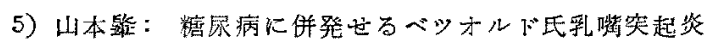
の治験例(特にインシニリンの齐果)，日耳率，37，206,

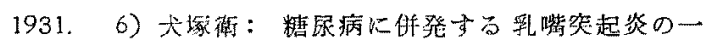
例, 耳喉，9，501，1936，7）佐藤日吉：糖尿病之急性

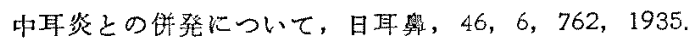

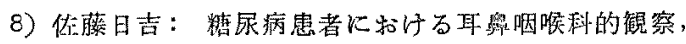
䎲喉, 11, 7, 637, 1938, 9) Bernfeld, K.: Mastoiditis bei Diabetes Mellitus. Monatschr. f.O.H. 60J. 980, 1926. 10) Olrik, B.: Affection de I'oreille chez les Diabetes. Acta Oto-Lar. Bd. V. 254, 1923.
9)上り引用. 11) Migind, H.: La trepanationde l'a pophyse mastoide chez les diabetiques. Acta otolar. da nsise Bd. V 118, 1923. 10) より引肘. 12) Grossmann: Handbuch der H.N.O. (Denker u. Kahler) Bd. 6，660, 上り引用. 13) Mering, J. und Minkowski, O.: Diabetes mellitusnach Pankreasexstirpation Zbl. Klin, med. S. 39.3, 1889, 18) より引 用. 14) Houssay, B.A., A. Biassoti \& C.T. Rictti: Action diabetogene de léxtrait antéhypophysaire. Compt. rend. Soc. de. biol, Tome III. S. 479, 1932. 18）上り引用. 15) Young, F.G.: (a) permanent experimental diabetes produced by pituitary (anterior lobe) injections, Lancet. Vol. 2, 372, 1937. (b) The diabetogenic action of crude anterior pituitary extracts. Bioch. J. Vol 32:512，1938，14) ¿ 口引用。 16) Dohan, F.C. \&: F.D.W. Lukens.: Experimental diabetes produced by the administraticn of Glucose. Endocr. Vol. 42, 244, 1948, 18) 上:り引用。17) Bailey, C.C. \& D.T. Bailey: The production of diabetes mellitus in rabits with alloxan. J. of Am. er. med Assoc, Vol. 122, S. 116\$1 1943. 18) 上り引用. 18）阔本耕造：猪尿病の实龭的研觉，綜合医学，9，7, 346, 1952. 19) 的場直矢, 小関要, 伝法弦, 佐藤辉 夫：歴代雄又は崔のみ Alloxan 精尿病の子孫家电の

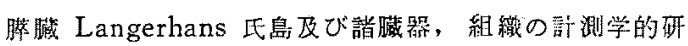
宛, 東北医学雑誌，54，3，256，1956，20）池本稳：幼

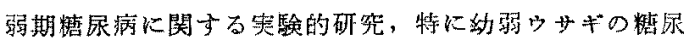
病の発症と経過について，神戸大医紀要，4, 2,692, 1953.

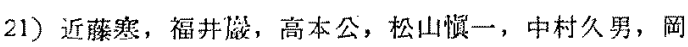
本健一，川口英二：Alloxan 糖尿病家臣の病理組織学 的研究，（○１）脳下垂体間脳副袩系（会），日本内分 泌学会雑誌，32，3，169，1956. 22) 平田幸正：Allo.

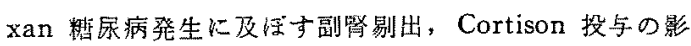
管, 日本内分泌学会稌誌，32，3，170，1956，23）衛藤

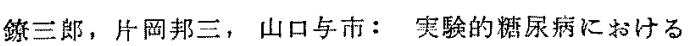
下活体，副婜系上植物神経系の関係（会），日本内分学 会䧴誌，32，3，172，1956，24）館石叔：精尿病之神

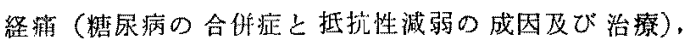
日本医事新報, No. 1609 ，3，1955。25）館石权, 吉田 秀堆, 島田克己, 高田久, 传藤杲達, 㣪藤典信, 北村一

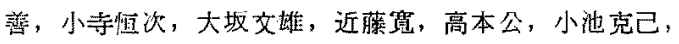
增田一郎：诺尿病汇関する研究(続報), 日本内科学会 棑誌，44，5，414，1955. 26）墙田一郎：生体防衛能 
老基整とせる穾駼的粒尿病に関寸る研究, 日本内分泌学 会雑誌，32，9，714，1956.27）苩并治郎：血液亚に

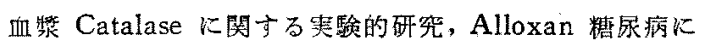

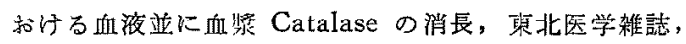

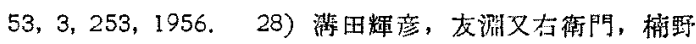
和一, 辻村久: 鈢疗病の代謝異常, 日本消化機病学会

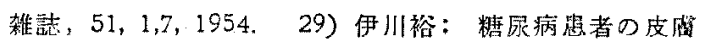

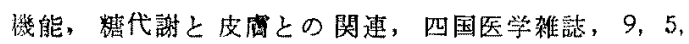
250, 1956. 30) 莲日正二：精尿病患者の骨䯠像に関 士万研究, 東北医学雑譩, $48,1,23,1953.31) 川$

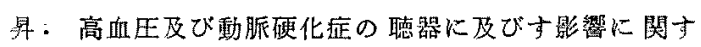
万実験的研究, 日耳辠, 46,4，701，1940, 32) 切替一

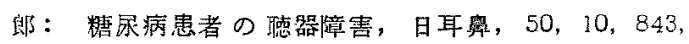

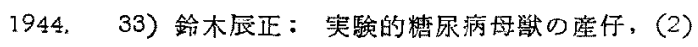
骨変化, 大阪汸立大学雑誌，6，1，30，1957。34）加藤

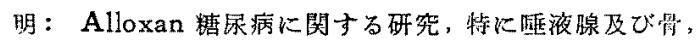
敕骨系統の变化, 千蕉医学会雑誌，31，3，323， 1955.

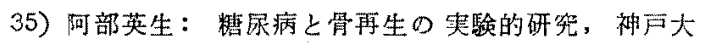
医紀要，10,2,397，1957.36) 古武弥人：糖疗病の 奏験的研究，䠦休消化機病学，2，9，539，1954.

\section{付図説 明}

第 1 図 No. 6, 糖尿病例, 菌泩入後 3 日目 鼓室, 粘膜の浮腫高度

第 2 図 No. 21 , 刘照例, 菌注入後3日目 袁室, 粠膜の浮腫中等度

第 3 图No７，䌅展病侧，菌注入後5日目 中耳胞，骨貿の吸収，新生を認るる。

第 4 图 No. 24 , 対照例, 菌注入後5日目 中耳胞, 骨の变化殆えどなし.

第 5 眮 No.4, 病病例, 菌注入後7日目
中臣胞，粘膜の浮腫充血出血高度

第 6 図 No. 18, 対照例，菌注入啳7日目 中五胞，粘膜の肥厚中等度，骨の吸収新生軽 度

第 7 图 No.4, 楼尿病例, 菌注入徭7日目 敨室, 粘瞙の出血及び骨吸収著明

第 8 図 No. 18, 刘照例, 菌这入後7日目 鼓室, 粘膜及び骨のの変化整度

第9区No. 3, 榶尿病例, 菌注入後 14 日目 中耳胞, 粘谟内出血, 受简状吸收渚明

第10国 No. 15, 封照例, 菌这入後 14 日目

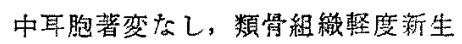

第11 図、No. 58, 糖尿病例, 菌注入後21日日 中耳胞，济出物があり骨の吸取新生認められ る.

第12国 No. 19.対照例, 菌注入後21日日

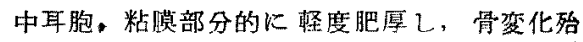
んどなし。

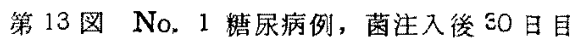
中耳胞，粘膜に腫小出血劲められる。

第14図No. 38, 対照例, 菌注入後30日目 中耳胞, 著変なし。

称を終るに臨み，御指導御䩒婞を賜つた恩師 故猿渡二郎教授, 本学病理学教室安保寿教授, 恩村堆太助教授, 耳咽喉科学教室平野新治教 授, 土田武正助教授に㳭謝すると共に，終始本 奏験に協力された教室の諸见沿謝致します

（原被到着=昭和 35.2.10日） 
高 川論文付図（I）
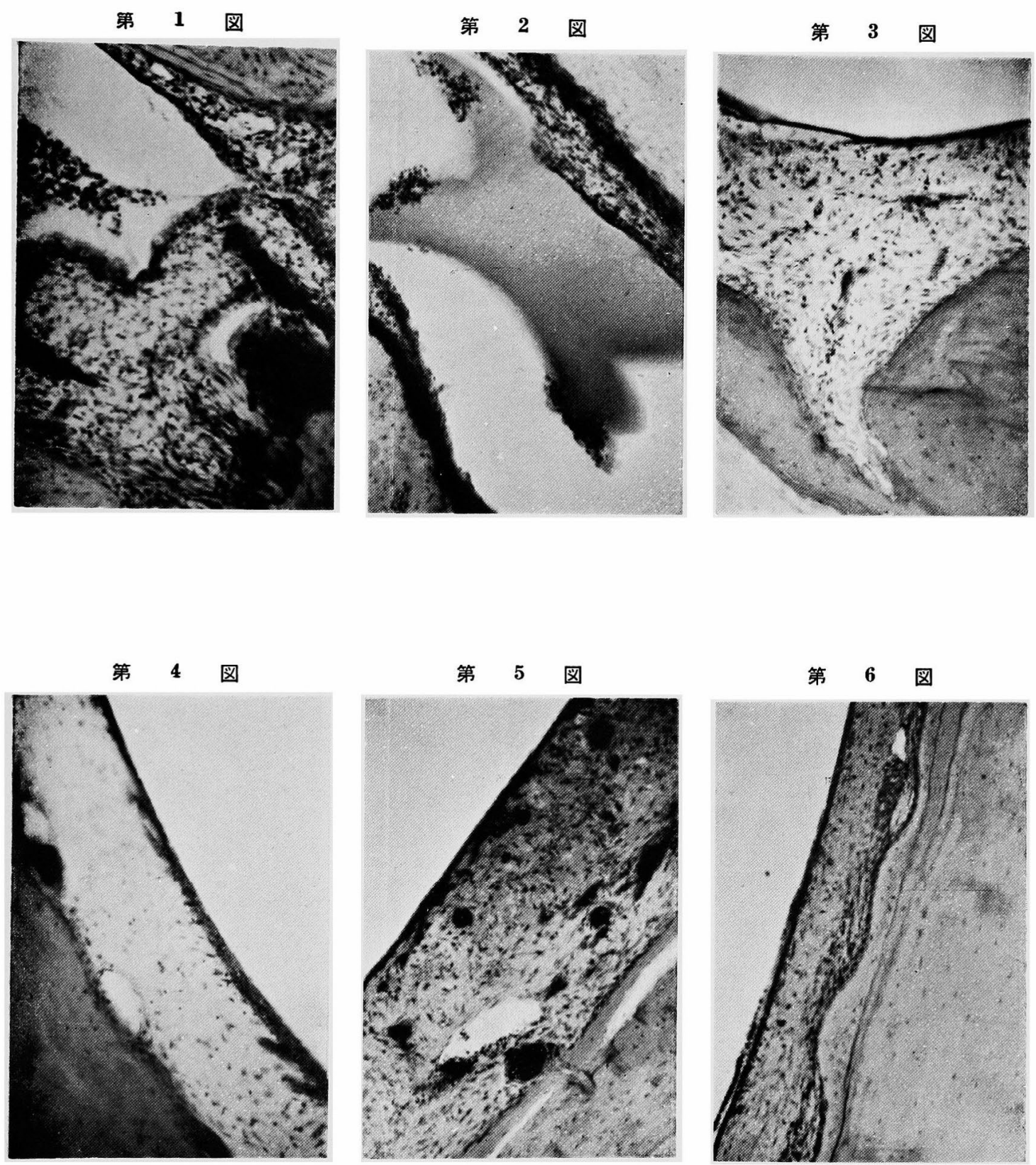
高川論文付図（『)
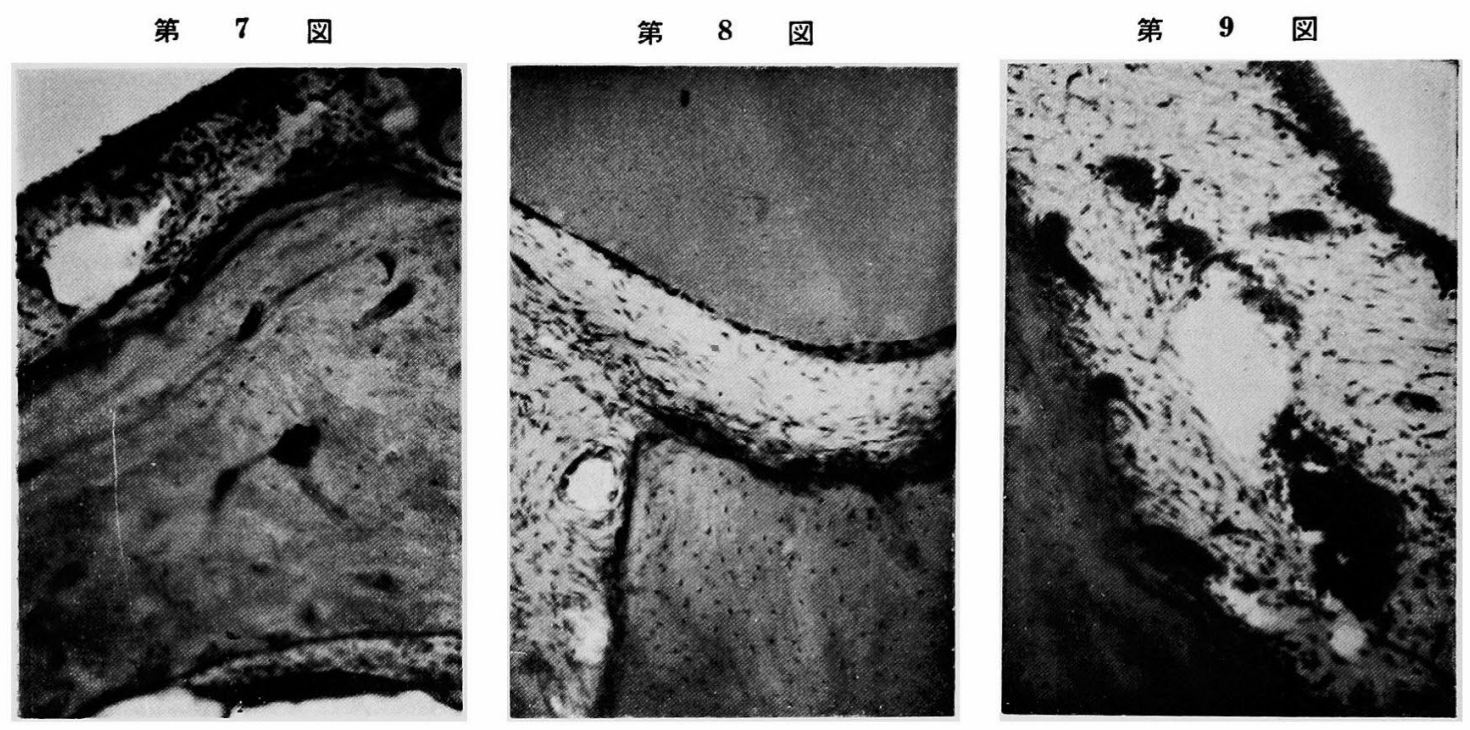

第 10 図

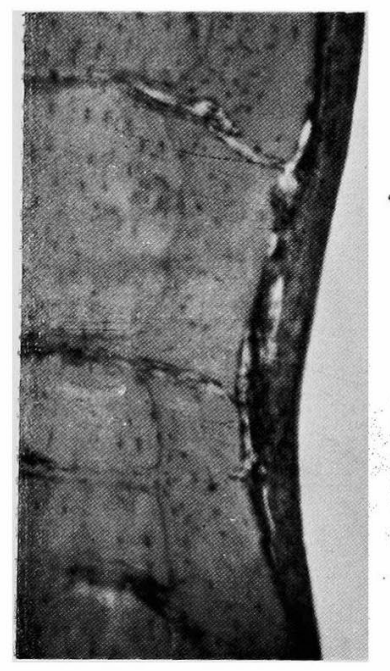

第 11 図

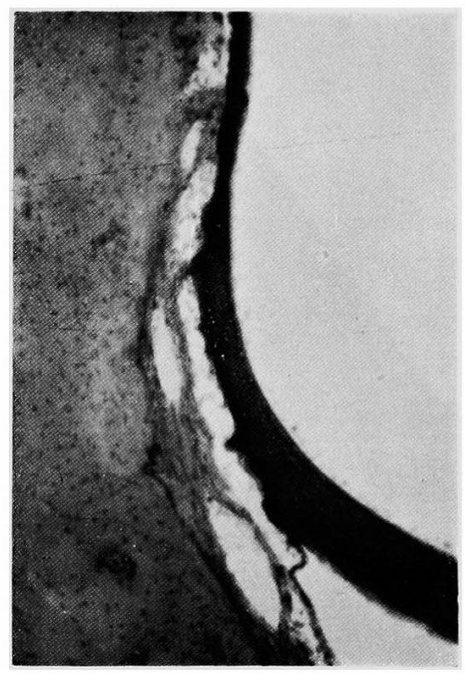

第 12 図

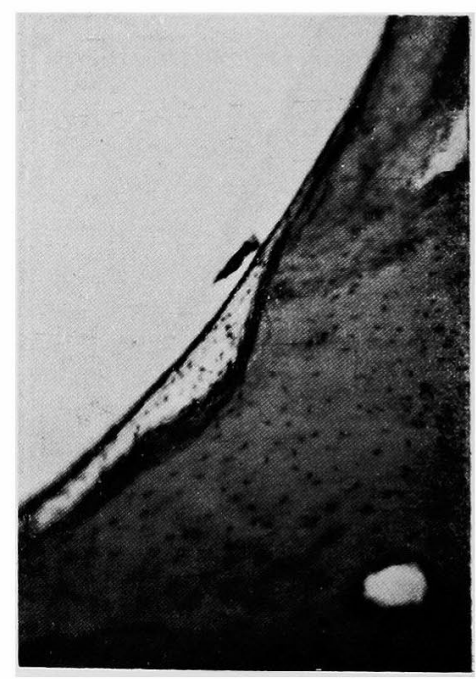




$$
\text { 高川論交付図（四） }
$$

第 13 図

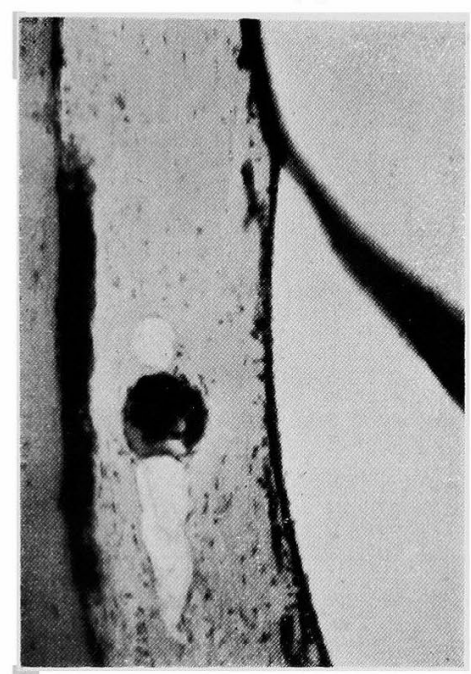

第 14 図

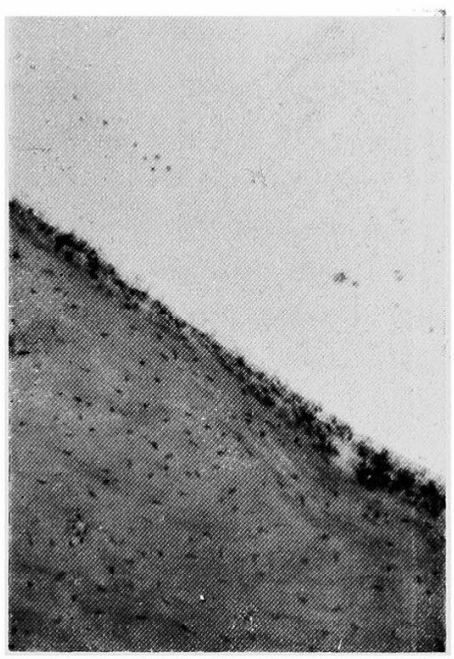

